Вельматов Анатолий Анатольевич, канд. с.-х. наук, научный сотрудник, Мордовский научно-исследовательский институт сельского хозяйства. Россия.

430904, Республика Мордовия, г. Саранск, пос. Ялга, ул. Мичурина, 5.

Тел.: (8342) 25-36-85.

Вельматов Анатолий Павлович, $\partial-p$ c.- $x$. наук, проф. кафедры «Технология производства и переработки сельскохозяйственной продукиии,, Национальный исследовательский Мордовский государственный университет имени Н.П. Огарева. Россия.

Тишкина Татьяна Николаевна, канд. с.-х. наук, старший преподаватель кафедры «Технология производства и переработки сельскохозяйственной продукиии», Национальный исследовательский Мордовский государственный университет имени Н.П. Огарева. Россия.

Абушаев Ренат Асымович, канд. с.-х. наук, старший преподаватель кафедры зоотехнии им. про- фессора С.А. Лапшина, Национальный исследовательский Мордовский государственный университет имени Н.П. Огарева. Россия.

Куликов Александр Александрович, аспирант кафедры «Технология производства и переработки сельскохозяйственной продукиии», Национальный исследовательский Мордовский государственный университет имени Н.П. Огарева. Россия.

Аль-Исави Али Абдуламир Хамза, аспирант кафедры «Технология производства и переработки сельскохозяйственной продукиии», Национальный исследовательский Мордовский государственный университет имени Н.П. Огарева. Россия.

430904, г. Саранск, ул. Большевистская, 68.

Тел.: (8342) 25-41-79.

Ключевые слова: порода; скрещивание; молочная продуктивность; жир; белок; воспроизводство; плодовитость.

\title{
THE DYNAMICS OF GROWTH, MILK YIELD AND REPRODUCTIVE QUALITY OF CROSSBRED SIMMENTAL $\times$ HOLSTEIN CATTLE
}

Velmatov Anatoljy Anatolyevich, Candidate of Agricultural Sciences, Researcher, Mordovia Research Institute. Russia.

Velmatov Anatoljy Pavlovich, Doctor of Agricultural Sciences, Professor of the chair "Production Technology and Processing of Agricultural Products", National Research Mordovia State Universityy named after N.P. Ogarev. Russia.

Tishkina Tatiana Nikolaevna, Candidate of Agricultural Sciences, Senior Teacher of the chair "Production Technology and Processing of Agricultural Products", National Research Mordovia State Universityy named after N.P. Ogarev. Russia.

Abushaev Renat Asymovich, Candidate of Agricultural Sciences, Senior Teacher of the chair "Zootechnic named after professor S.A. Lapshin", National Research Mordovia State Universityy named after N.P. Ogarev. Russia.

Kulikov Aleksandr Aleksandrovich, Post-graduate Student of the chair "Production Technology and Processing of Agricultural Products", National Research Mordovia State Universityy named after N.P. Ogarev. Russia.
Al-Isavi Ali Abdulamir Hamza, Post-graduate Student of the chair "Production Technology and Processing of Agricultural Products", National Research Mordovia State Universityy named after N.P. Ogarev. Russia.

Keywords: breed; crossbreeding; milk yield; fat; protein; reproduction; fecundity.

It is established that a half-breed animals are superior in live weight of their counterparts, depending on the genotype at 12 months $23.0-32.5 \mathrm{~kg}$ in 15-month age, these differences constitute $22,0-34,6 \mathrm{~kg}$ and 18 months of age, respectively, and 20.738 .3 per $\mathrm{kg}$. Milk yield of cows in second and third generation Simmental outperform peers on 680 $\mathrm{kg}$ and $803 \mathrm{~kg}$. content of the mass fraction of fat in milk marked superiority of Simmental cows over their peers by 0.04 to $0.13 \%$, and the content of the mass fraction of protein Simmental crossbred animals exceed 0.02 and $0.12 \%$.

УдК 636.322.012(082)

\section{ОСОБЕННОСТИ ПИТАНИЯ МОЛОДНЯКА КРУПНОГО РОГАТОГО СКОТА}

\author{
ГОЛОВЕЙ Валентин Васильевич, Новгородский государственный университет \\ имени Ярослава Мудрого
}

ВЯЙЗЕНЕН Геннадий Николаевич, Новгородский государственный университет имени Ярослава Мудрого

ТИМОШКИНА Елена Александровна, Новгородский государственный университет имени Ярослава Мудрого

ПАТРУШЕВА Ольга Ивановна, Новгородский государственный университет имени Ярослава Мудрого

ТОКАРЬ Александр Иванович, Новгородский государственный университет имени Ярослава Мудрого

Приведены нормы содержания тяжелых металлов в рационе молодняка крупного рогатого скота черно-пестрой породы в возрасте 1-6 месяцев в зоне техногенного загрязнения окружающей среды.

Введение. При выращивании молодняка крупного рогатого скота в зоне техногенного загрязнения окружающей среды (химическое предприятие ОАО «Акрон», ТЭЦ-2, ме- таллургический завод) необходимо выявлять степень загрязнения тяжелыми металлами организма молодняка со дня рождения до окончания молозивного периода выращивания. 
В этот очень ответственный период начала жизни новорожденного с потреблением молозива, единственного продукта питания, происходит «передача» ряда тяжелых металлов потомству через организм матерей $[1,2,5]$. В дальнейшем в связи с увеличением возраста, интенсивности роста, адаптации организма к новым условиям жизнеобеспечения, потребления молочных и растительных кормов, воды питьевой организм молодняка подвергается, к сожалению, загрязнению тяжелыми металлами [3-4].

Цель исследований - определить нормы потребления тяжелых металлов молодняком от рождения до 6-месячного возраста.

Методика исследований. Исследования проводили в соответствии со схемой опыта (табл. 1).

В первом и единственном продукте для новорожденных телят - молозиве отмечено 0-0,01 мг/кг свинца, 0,08-0,14 мг/кг хрома, 0,03-0,18 мг/кг никеля, 0-0,23 мг/кг меди, 0-0,81 мг/кг стронция стабильного, 010,02 мг/кг цинка. Такое содержание тяжелых металлов в молозиве коров установлено в первый день после отела при скармливании им основного (хозяйственного) рациона с включением злакового сена (без ККС в почве).

При сложившейся системе выращивания молодняка крупного рогатого скота (пониженных приростах живой массы в первые 3 месяца и получение более высоких приростов в последующем) израсходовано следующее количество кормов: 246 л молока цельного, 660 л молока обезжиренного (натурального), 540 л сыворот- ки молочной, 267 кг сена, 485 кг силоса, 64 кг зерновых концентратов и 1400 л питьевой воды. В первые 3 месяца жизни молодняка среднесуточные приросты живой массы составляли 210380 г, а в возрасте 4-6 месяцев - 776-787 г в расчете на одну голову.

В молозивный период выращивания телят в рационах содержалось следующее количество тяжелых металлов, мг: 0,04 кадмия, 0,51 свинца, 0,27 хрома, 1,13 меди, 4,78 цинка, 12,43 марганца и 6,10 олова.

В первый месяц выращивания телочек в рационы растительные кормовые добавки не включали. Их включали в рационы молодняка в возрасте 2-6 месяцев. Концентрация тяжелых металлов в рационах приведена в табл. 2 .

Коровы-матери и молодняк потребляли корма, произведенные в данном хозяйстве. Поение водой осуществляли из автопоилок. Учет потребляемых кормов и их остатков проводили путем взвешивания ежесуточно. Молодняку в возрасте 2-6 месяцев давали кормовые добавки в составе комбикорма в дозе 30 г на одну голову в сутки.

Результаты исследований. Динамика живой массы и среднесуточных приростов молодня$\kappa a$. При данной системе выращивания молодняка отмечали динамику живой массы, представленную в табл. 3.

Живая масса молодняка опытных групп в возрасте 1 месяц колебалась от $36,5 \pm 0,30$ кг до $37,8 \pm 0,41$ кг против $36,7 \pm 0,40$ кг у аналогов I контрольной группы $(P<0,05)$. В этом возрасте у молодняка II контрольной группы живая масса

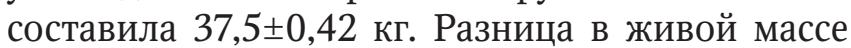
молодняка между первой и второй контрольны-

Таблица 1

Схема научно-хозяйственного опыта на молодняке крупного рогатого скота

\begin{tabular}{|l|l|c|c|}
\hline $\begin{array}{c}\text { Группа молодняка } \\
\text { в возрасте } \\
1-6 \text { месяцев }\end{array}$ & \multicolumn{1}{|c|}{ Условия кормления } & $\begin{array}{c}\text { Живая масса } \\
\text { телят при } \\
\text { рождении, кг }\end{array}$ & $\begin{array}{c}\text { Количество } \\
\text { молодняка грппе, гол. }\end{array}$ \\
\hline І контрольная & Основной рацион (ОР) сено «традиционное», без ККС & $30,3 \pm 0,20$ & 10 \\
\hline II контрольная & ОР + сено с ККС, без добавок & $31,1 \pm 0,10$ & 10 \\
\hline 1-я опытная & ОР + сено с ККС + мука татарника (Onopordum acanthium L.) & $31,4 \pm 0,20$ & 10 \\
\hline 2-я опытная & ОР + сено с ККС + мука кипрея (Chamaenerion angustifolium L.) & $30,8 \pm 0,20$ & 10 \\
\hline 3-я опытная & ОР + сено с ККС + мука донника белого (Melilotus albus Desz.) & $30,2 \pm 0,10$ & 10 \\
\hline 4-я опытная & ОР + сено с ККС + мука стеблей бобов кормовых (Faba vulgaris Moensh.) & $30,7 \pm 0,80$ & 10 \\
\hline
\end{tabular}

При мечан ие: ККС - карбонат кальция химического синтеза, внесенный в почву для выращивания трав на сено.

Таблица 2

Концентрация тяжелых металлов в рационах молодняка крупного рогатого скота, мг

\begin{tabular}{|c|c|c|c|c|c|c|c|}
\hline $\begin{array}{c}\text { Возраст, } \\
\text { мес. }\end{array}$ & Кадмий & Хром & Медь & Свинец & Цинк & Марганец & Олово \\
\hline 2 & $0,2617 / 0,1396$ & $1,6011 / 0,8541$ & $7,3828 / 3,9384$ & $3,2352 / 1,7258$ & $32,1560 / 17,1536$ & $79,6102 / 42,4680$ & $21,5282 / 11,4842$ \\
\hline 3 & $0,4415 / 0,3845$ & $2,550 / 2,2215$ & $8,820 / 7,6828$ & $5,080 / 0,7427$ & $47,030 / 40,960$ & $99,350 / 86,540$ & $22,2990 / 19,4233$ \\
\hline 4 & $0,512 / 0,4549$ & $4,260 / 3,786$ & $13,16 / 11,695$ & $6,438 / 5,720$ & $56,98 / 50,63$ & $174,56 / 155,113$ & $33,9040 / 30,1261$ \\
\hline 5 & $0,6615 / 0,705$ & $6,071 / 6,47$ & $18,73 / 19,97$ & $8,15 / 8,69$ & $72,68 / 77,48$ & $251,16 / 267,45$ & $46,3544 / 49,467$ \\
\hline 6 & $0,81 / 0,695$ & $8,39 / 7,198$ & $19,74 / 16,93$ & $8,578 / 7,36$ & $76,66 / 65,74$ & $265,26 / 227,48$ & $52,7929 / 45,2741$ \\
\hline
\end{tabular}

Примечание: в числителе - в расчете на 1 кг сухого вещества, мг, в знаменателе - на 1 энерг. к. ед., мг. 
Живая масса молодняка крупного рогатого скота в возрасте 1-6 месяцев, кг

\begin{tabular}{|l|c|c|c|c|c|c|}
\hline \multirow{2}{*}{\multicolumn{1}{|c|}{ Группа молодняка }} & \multicolumn{7}{|c|}{ Живая масса 1 гол. в возрасте, мес. } \\
\cline { 2 - 7 } & 1 & 2 & 3 & 4 & 5 & 6 \\
\hline I контрольная & $36,7 \pm 0,40$ & $44,6 \pm 0,10$ & $55,8 \pm 0,11$ & $79,2 \pm 0,12$ & $102,5 \pm 0,15$ & $125,9 \pm 0,21$ \\
\hline II контрольная & $37,5 \pm 0,42$ & $45,5 \pm 0,12$ & $56,8 \pm 0,12$ & $80,1 \pm 0,12$ & $103,5 \pm 0,18$ & $127,0 \pm 0,27$ \\
\hline 1-я опытная & $37,8 \pm 0,41$ & $46,0 \pm 0,13$ & $57,2 \pm 0,13$ & $80,6 \pm 0,11$ & $104,1 \pm 0,20$ & $127,7 \pm 0,35$ \\
\hline 2-я опытная & $37,1 \pm 0,35$ & $45,3 \pm 0,12$ & $56,7 \pm 0,11$ & $80,3 \pm 0,12$ & $103,8 \pm 0,18$ & $127,3 \pm 0,26$ \\
\hline 3-я опытная & $36,5 \pm 0,30$ & $44,4 \pm 0,11$ & $55,8 \pm 0,12$ & $79,3 \pm 0,13$ & $102,9 \pm 0,17$ & $126,5 \pm 0,30$ \\
\hline 4-я опытная & $37,1 \pm 0,28$ & $45,4 \pm 0,12$ & $56,6 \pm 0,13$ & $79,9 \pm 0,11$ & $103,4 \pm 0,18$ & $126,9 \pm 0,28$ \\
\hline В среднем & $37,1 \pm 0,29$ & $45,2 \pm 0,12$ & $56,5 \pm 0,13$ & $79,9 \pm 0,11$ & $103,4 \pm 0,18$ & $126,9 \pm 0,28$ \\
\hline
\end{tabular}

ми группами была равна 0,8 кг, т.е. статистически недостоверна $(P>0,05)$.

У животных опытных групп живая масса варьировала от $126,9 \pm 0,28$ до $127,7 \pm 0,35$ кг против $125,9 \pm 0,21$ кг у аналогов I контрольной группы на 6-й месяц выращивания. Молодняку двух контрольных групп в составе суточных рационов не давали добавок растительного происхождения.

Кормовые добавки в дозе 30 г/гол./сут. в соответствии со схемой опыта скармливали на фоне основного рациона. Их применяли в основном для снижения или ликвидации степени загрязненности организма тяжелыми металлами.

Среднесуточные приросты живой массы молодняка за период выращивания приведены в табл. 4. У животных опытных групп приросты составляли от $785 \pm 0,26$ до $787 \pm 0,30$ г против $781 \pm 0,21$ г у аналогов I контрольной группы $(P<0,001)$. У животных II контрольной группы среднесуточные приросты живой массы составляли 784 $\pm 0,27$ г, что несколько ниже, чем у молодняка при использовании растительных кормовых добавок.

Принции нормирования. Основные принципы нормирования содержания тяжелых металлов в кормлении молодняка крупного рогатого скота в возрасте 1-6 месяцев - суточный рацион, 1 кг сухого вещества, 1 кормовая единица (1 энергетическая кормовая единица) и 1 кг живой массы. При разработке полноценной системы выращивания молодняка, в частности в регионах активной деятельности крупнейших промышленных предприятий, использования и переработки первичных и вторичных отходов, учтены нормы содержания ряда тяжелых металлов в рационе (табл. 5).

Это содержание тяжелых металлов в кормлении молодняка тесно связано с динамикой сред- несуточных приростов живой массы и массой тела животных, выращенных на ферме, расположенной на расстоянии 8-9 км от химического предприятия ОАО «Акрон», ТЭЦ-2, металлургического завода в Новгородской области.

Балансы ряда тяжелых металлов в организме молодняка крупного рогатого скота в возрасте 1-6 месяцев. Кормовые добавки растительного происхождения (татарник, кипрей узколистный, донник белый и стебли бобов кормовых) активизируют экскрецию тяжелых металлов через желудочно-кишечный тракт. Тестом активной экскреции тяжелых металлов следует считать очистку организма с учетом отрицательного баланса каждого из этих токсикантов за все временные периоды выращивания.

Отрицательный баланс кадмия (период полураспада) в организме телочек в возрасте 1 месяц составил $-0,01778$ мг в случае применения муки донника белого. В 4 месяца баланс кадмия составил $-0,8077$ мг (донник белый), а в 6 месяцев $-1,245$ мг (татарник).

Молодняк в 2-месячном возрасте, потреблявший в составе суточного рациона муку татарника, имел баланс хрома -6,6153 мг против $-3,9744$ мг в контроле. Использование различных лекарственных трав в составе рациона способствовало активизации экскреции хрома из организма. В этом возрасте баланс хрома в организме варьировал в зависимости от вида, ботанического, химического состава и фармакологических свойств кормовых добавок. В частности, от $-2,0827$ мг (мука стеблей бобов кормовых) до -8,4896 мг (донник белый). В случае применения кипрея этот показатель был равен $-5,1124$ мг.

У молодняка в 3 месяца за счет повышения интенсивности экскреции с калом баланс хрома

Таблица 4

Приросты живой массы молодняка крупного рогатого скота в расчете на одну голову в сутки

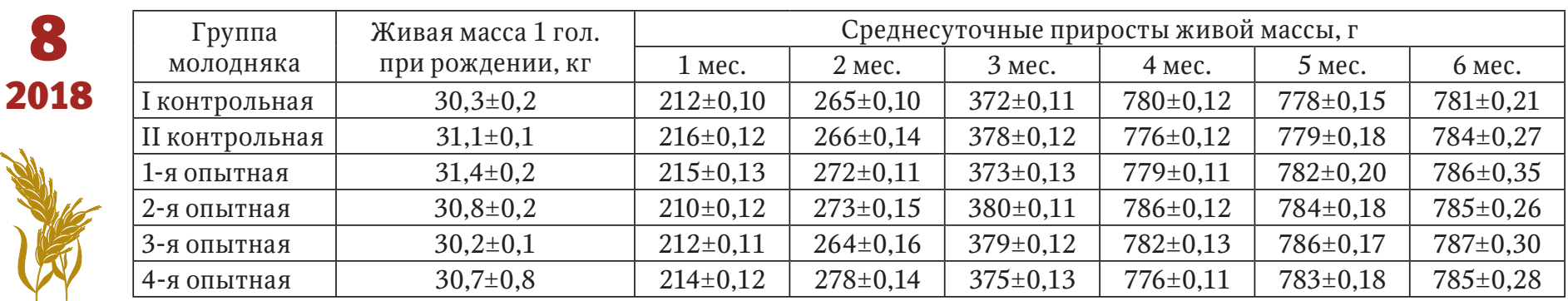


Нормы содержания тяжелых металлов в кормлении молодняка крупного рогатого скота в возрасте 1-6 месяцев, мг/гол./сут.

\begin{tabular}{|c|c|c|c|c|}
\hline \multirow{2}{*}{ Тяжелый металл } & \multicolumn{4}{|c|}{ В расчете на } \\
\hline & суточный рацион & 1 кг сухого вещества & 1 энерг. к. ед. & 1 кг живой массы \\
\hline \multicolumn{5}{|c|}{ Возраст 1 месяц } \\
\hline Кадмий & 0,04 & 0,05 & 0,02 & 0,001 \\
\hline Свинец & $0,51-1,05$ & $0,64-1,31$ & $0,24-0,49$ & $0,014-0,03$ \\
\hline Хром & $0,27-0,46$ & $0,34-0,57$ & $0,12-0,21$ & $0,007-0,012$ \\
\hline Медь & $1,13-2,99$ & $1,41-3,74$ & $0,52-1,39$ & $0,03-0,08$ \\
\hline Цинк & $4,78-31,60$ & $5,97-39,50$ & $2,22-14,70$ & $0,13-0,85$ \\
\hline Марганец & 12,43 & 15,54 & 5,78 & 0,33 \\
\hline Олово & $6,10-12,92$ & $7,59-16,07$ & $2,84-6,02$ & 0,17 \\
\hline \multicolumn{5}{|c|}{ Возраст 2 месяца } \\
\hline Кадмий & 0,13 & 0,25 & 0,13 & 0,003 \\
\hline Свинец & $1,63-1,83$ & $3,13-3,52$ & $1,66-1,87$ & $0,03-0,04$ \\
\hline Хром & $0,75-0,94$ & $1,44-1,81$ & $0,76-0,96$ & $0,017-0,021$ \\
\hline Медь & $3,62-4,31$ & $6,96-8,29$ & $3,69-4,40$ & $0,08-0,09$ \\
\hline Цинк & $15,16-24,99$ & $29,15-48,05$ & $15,47-25,50$ & $0,33-0,55$ \\
\hline Марганец & 41,53 & 79,86 & 42,38 & 0,92 \\
\hline Олово & 11,25 & 21,53 & 11,48 & 0,25 \\
\hline \multicolumn{5}{|c|}{ Возраст 3 месяца } \\
\hline Кадмий & 0,85 & 0,44 & 0,38 & 0,015 \\
\hline Свинец & 9,78 & 5,09 & 4,42 & 0,17 \\
\hline Хром & 4,91 & 2,56 & 2,22 & 0,09 \\
\hline Медь & 16,98 & 8,84 & 7,68 & 0,30 \\
\hline Цинк & 90,52 & 47,14 & 40,96 & 1,60 \\
\hline Марганец & 191,26 & 99,61 & 86,54 & 3,38 \\
\hline Олово & 42,93 & 22,30 & 19,42 & 0,77 \\
\hline \multicolumn{5}{|c|}{ Возраст 4 месяца } \\
\hline Кадмий & 1,59 & 0,51 & 0,45 & 0,02 \\
\hline Свинец & 20,02 & 6,44 & 5,72 & 0,25 \\
\hline Хром & 13,25 & 4,26 & 3,78 & 0,16 \\
\hline Медь & 40,93 & 13,16 & 11,69 & 0,51 \\
\hline Цинк & 177,21 & 56,98 & 50,63 & 2,22 \\
\hline Марганец & 542,90 & 174,56 & 155,11 & 6,79 \\
\hline Олово & 105,44 & 33,90 & 30,13 & 1,33 \\
\hline \multicolumn{5}{|c|}{ Возраст 5 месяцев } \\
\hline Кадмий & 3,10 & 0,66 & 0,71 & 0,03 \\
\hline Свинец & 38,16 & 8,15 & 8,69 & 0,37 \\
\hline Хром & 28,41 & 6,07 & 6,47 & 0,27 \\
\hline Медь & 87,66 & 18,73 & 19,97 & 0,85 \\
\hline Цинк & 340,12 & 72,67 & 77,48 & 3,29 \\
\hline Марганец & 1175,42 & 251,16 & 267,75 & 11,37 \\
\hline Олово & 216,94 & 46,35 & 49,47 & 2,12 \\
\hline \multicolumn{5}{|c|}{ Возраст 6 месяцев } \\
\hline Кадмий & 4,54 & 0,81 & 0,69 & 0,036 \\
\hline Свинец & 48,04 & 8,58 & 7,35 & 0,38 \\
\hline Хром & 47,00 & 8,39 & 7,20 & 0,37 \\
\hline Медь & 110,56 & 19,74 & 16,93 & 0,87 \\
\hline Цинк & 429,27 & 76,65 & 65,74 & 3,38 \\
\hline Марганец & 1485,44 & 265,26 & 227,48 & 11,70 \\
\hline Олово & 295,64 & 52,79 & 45,27 & 2,35 \\
\hline
\end{tabular}


в организме с отрицательным знаком. В этом возрасте у молодняка как контрольных, так и опытных групп баланс хрома колебался от $-1,021$ мг (татарник) до -6,7685 мг (кипрей). У молодняка I контрольной группы он был равен $-36,4493$ мг, a II контрольной группы -22,5919 мг.

В зависимости от увеличения возраста появлялась тенденция к интенсивности выделения хрома с калом, в меньшей степени с мочой. У молодняка в возрасте 6 месяцев выявлен отрицательный баланс хрома в организме при использовании донника белого (-6,932 мг) и татарника (-42,6375 мг). У животных I и II контрольных групп баланс хрома составил соответственно $-6,2269$ мг и $-17,457$ мг.

Из многообразия растительных кормовых добавок наиболее существенное влияние на степень снижения загрязненности свинцом организма молодняка в разные сроки выращивания оказали в 1 месяц татарник (-0,7016 мг), стебли бобов кормовых $(-0,2008$ мг); в 2 месяца - донник белый $(-0,2023$ мг), татарник $(-0,9927$ мг), стебли бобов кормовых (-1,2238 мг); в 3 месяца - донник белый $(-5,3755$ мг); в 4 месяца донник белый (-9,0185 мг), стебли бобов кормовых (-21,3905 мг); в 5 месяцев - донник белый (-57,0063 мг); в 6 месяцев - стебли бобов кормовых $(-16,7015 \mathrm{мг})$.

Заключение. В условиях выращивания молодняка крупного рогатого скота при пониженных приростах живой массы в первые 3 месяца жизни и более высоких приростах в последующем установлено, что при высокой степени экскреции меди с калом и меньшей степени с мочой в зоне техногенного загрязнения отмечен отрицательный баланс этого элемента в организме животных как контрольных, так и опытных групп. Существенное снижение ретенции меди в организме в какой-то степени объясняется на генетико-эволюционном уровне животных за счет внутренних резервов и уровня ретенции, что в сочетании с плацентарным барьером создает оптимальные условия для внутриутробного развития эмбриона, плода.

Избытки содержания марганца и цинка в рационах молодняка крупного рогатого скота устранены за счет использования кипрея и донника белого в составе кормосмеси.

\section{СПИСОК ЛИТЕРАТУРЫ}

1. Андреев А.И., Митина Н.А. Изменение гематологических показателей при разных уровнях кормления // Ресурсосберегающие технологии получения сельскохозяйственной продукции. Лапшинские чтения. - Саранск, 2010. - С. 30-32.

2. Бабий Н.В. Методические подходы к реализации концепции фитопрофилактики // Хранение и переработка сельхозсырья. - 2016. - № 6. - С. 38-42.

3. Выведение тяжелых металлов и радионуклидов из организма сельскохозяйственных животных / Г.Н. Вяйзенен [и др.]. - Великий Новгород: Печатный двор, 2010. - 424 с.

4. Ерофеев В.И. Стратегия выращивания ремонтного молодняка КРС в молочный период // Ресурсосберегающие экологически безопасные технологии получения сельскохозяйственной продукции. Лапшинские чтения. - Саранск, 2010. - С. 68-70.

5. Получение экологически безопасной зерновой продукции на антропогеннозагрязненных территориях Саратовской области / Ю.М. Андриянова [и др.] // Аграрный научный журнал. - 2016. № 3. - С. 8-13.

Головей Валентин Васильевич, канд. с.- $x$. наук, научный сотрудник кафедры «Животноводство», Новгородский государственный университет имени Ярослава Мудрого. Россия.

Вяйзенен Геннадий Николаевич, $\partial-p$ c. $-x$. наук, проф. кафедры «Животноводство», Новгородский государственный университет имени Ярослава Мудрого. Россия.

Тимошкина Елена Александровна, канд. с.- $x$. наук, научный сотрудник кафедры «Животноводство», Новгородский государственный университет имени Ярослава Мудрого. Россия.

Патрушева Ольга Ивановна, канд. с.-х. наук, научный сотрудник кафедры «Животноводство», Новгородский государственный университет имени Ярослава Мудрого. Россия.

Токарь Александр Иванович, $\partial-p$ c.- $x$. наук, проф. кафедры «Животноводство», Новгородский государственный университет имени Ярослава Мудрого. Россия.

173000, г. Великий Новгород, ул. Большая СанктПетербургская, 41.

Тел.: (8162) 62-72-44.

Ключевые слова: телята; возраст 1-6 месяцев; рационы; кормовые добавки; тяжелые металлы; живая масса; приросты.

\section{PECULIARITIES OF CALVES FEEDING}

Golovey Valentin Vasilyevich, Candidate of Agricultural Sciences, Researcher of the chair "Animal Industry", Novgorod State University named after Yaroslav Mudriy. Russia.

Viaisenen Gennadiy Nikolaevich, Doctor of Agricultural Sciences, Professor of the chair "Animal Industry", Novgorod State University named after Yaroslav Mudriy. Russia.

Timoshkina Elena Aleksandrovna, Candidate of $\mathrm{Ag}$ ricultural Sciences, Researcher of the chair "Animal Industry", Novgorod State University named after Yaroslav Mudriy. Russia.

Patrusheva Olga Ivanovna, Candidate of Agricultural Sciences, Researcher of the chair "Animal Industry",
Novgorod State University named after Yaroslav Mudriy. Russia.

Tokar Aleksander Ivanovich, Doctor of Agricultural Sciences, Professor of the chair "Animal Industry", Novgorod State University named after Yaroslav Mudriy. Russia.

Keywords: calves; age 1-6 month; rations; feeding additives; heavy metals; lieweight daily gains.

The heavy metals concentration in rations of calves black-and-white breed at the age of 1-6 month at the zone of industrial enterprisers pollution were investigated. 